\title{
EVALUATION OF POST TENSIONED SLAB AND ITS CONTRAST WITH TRADITIONAL RCC SLAB: REVIEW
}

\author{
Siddiqui Furkhan Ahmed \\ Student, Department of Civil Engineering \\ Shri Guru Gobind Singhji Institute of Technology, Nanded, Maharashtra, India.
}

\begin{abstract}
Post-tensioning is a technique for reinforcing concrete slabs with high-strength tendons. Tendons retain much more concrete in compression. Posttension floors are capable of bearing almost every dead load due to their tensioned tendons, which aid to perform live loads acts on slabs \& make them stronger than traditional slabs. For commercial and residential floors, PT slabs are suggested for comparatively limited depths, less heavy weights and free floor elevation. The research on the R.C.C and PT slab has been reviewed, with an integrative impact with the lateral load. The primary aim of this, is to review the reaction and behavioural characteristics of the post-tension flat plate during an earthquake and to contrast it with the traditional slab. For this purpose, the past papers related to the PT slab were studied and a successful conclusion has been made.
\end{abstract}

Keywords - Post-tensioned slab, Traditional RCC slab, Flat plate, Cost Comparison.

\section{INTRODUCTION}

In these days, the demand for high-rise structures has risen. Multi-story structures for both commercial and residential uses can be built to maintain a larger load than needed for safety purposes. Several techniques are used for the safety aspect of the structure, including post-tensioning. Post-tensioned construction is a concept that is constantly being used in the building sector today. This form of concrete reinforcement helps a designer to gain considerable advantages of prestressed concrete while keeping the efficiency of the cast-inplace construction method.

A tensioned slab may be a pre-casted or cast in situ that uses the pre-stress theory. For wide beamless spans, post-tensioned slabs are very popular. High strength pre-stress cables are the key components which help to sustain the slab in compression throughout its lifespan. PT slabs are usually flat plates, band beams, or ribbed plates. PT slabs provide the thinnest form of plates, since concrete is exploited to its strengths and mostly put concrete in compression. Post-tension plates are tensed steel strings that use heavy strength to compact the width of the plates holding the bulk of the concrete in compression. This offers a very effective structure that reduces the use of resources and reduces the economic span context related to reinforced concrete.

The method of development of prestressed concrete, masonry and other structural elements after tensioning is easy. The word pre-stressing is used to define the method of introducing internal forces into a concrete \& steel component during the development process to overcome the external loads when the structure is used (known as service loads). The internal forces are applied with high-strength steel tensioning that can be achieved prior to or after placing the concrete. As the steel is tensed before the concrete cast this method is pre-tensioning. The method is called post-tensioning as the steel is tensioned after concrete casting. Because pre-tensioning involves specifically built casting beds, it is usually used to create basic shapes that can be trucked to a place of work during the precast manufacturing process. Post-tensioning takes place on site by adding post-tensioning tendons in a way identical to the placement of rebars inside the concrete job.

\section{LOADING PHASES}

\section{A. Initial Phase -}

The component is under pre-stress but not exposed to any additional super imposed loads. This stage may be further subdivided.

1. Prior to pre-stressing: Concrete is poor in load bearing. Support Yielding must be stopped. During pre-stress:

- Steel: This phase is crucial for tendon capacity. At this phase, the full stress under which the wires are exposed throughout their lives will occur.

- Concrete: Since the concrete did not aged, concrete would be crushed at anchorages when the consistency is lower or the concrete is honeycombed. To prevent 


\section{International Journal of Engineering Applied Sciences and Technology, 2021 \\ Vol. 6, Issue 1, ISSN No. 2455-2143, Pages 117-121 \\ Published Online May 2021 in IJEAST (http://www.ijeast.com)}

over strengths in the concrete, the pre-stress order is essential.

2. For pre-tensioned components, where transition is within a brief time, and for post-tensioned components where transfer might be incremental, there are no additional loads on the individual but for the member's own weight.

3. De-shuttering: withdrawal of formwork must be thoughtful in design. This initial pre-stress is a critical condition in the concrete which also determines the nature of the component.

\section{B. Final Phase -}

This is the stage where the model is loaded with specific working loads. The designer should recognize the different configurations of imposed loads on each part of the building with lateral loads such as seismic forces, wind forces and strain loads generated by settlements of supports. In this phase, the main loads are:

1. Sustained load: It is also advisable to restrict the deflection under sustained loads since these loads are the ones that do them the most damage.

2. Working load: The member must adhere to the necessary working load. A check between excess stress and deflection must be established. However, this structure does not have enough support for handling incredibly heavy loads.

3. Cracking load: When a pre-stress member experiences a crack, it signals a rapid shift in stress and pressure. This is often an essential phase.

4. Ultimate load: The capacity of the member, which denotes the load limit before failure.

\section{RELATIVE STUDY BETWEEN TRADITIONAL RCC \& PT SLAB}

The slabs are described in two categories i.e., one-way slabs and two-way slabs. In a rectangular slab ratio of ly/lx is less than 2 or equal to 2 then it is called as two-way slab. These slabs are classified into the following form according to the building safety element, architectural vision and the net cost of construction.
a) Traditional slab.
b) Post-tensioned slab.
c) Flat plate.
d) Flat slab with drop.
e) Waffle slab.

Here, it can be much more beneficial by contemplating both the post-tension plate and the flat plate together than conventional RCC plate. The relative inspection of the conventional and post-tensioned plate was seen. As compared with the conventional plate structure, the overall weight of the
PT plate is very low. The PT slab floor system is less costly than the conventional slab floor structure, because of cost effectiveness. Likewise, the post-tension system prompts a new

aesthetic view of the building which allows for higher roof heights and the architectural versatility of the building when compared with conventional slab construction.

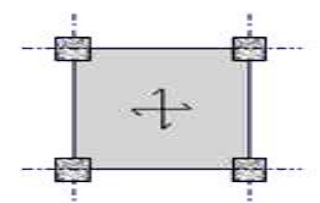

a) Flat plate

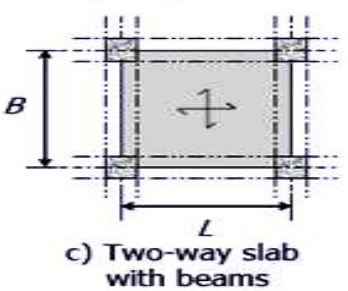

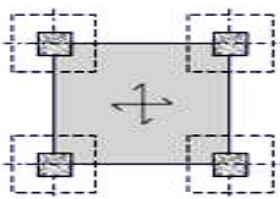

b) Flat slab

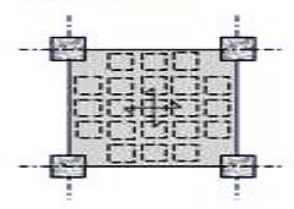

d) Waffle slab
Fig. 1. Various types of slab.

Using the traditional form of building, which is the most commonly practiced technique, a slab rests on beams and supported by columns. This is called the technique of beam slab load transfer. Due to the conventional building method, the ceiling height is lower. To enhance the architectural and structural aspects of multi-story, industrial structures, factories, and other places, slabs are mounted directly to columns. slab built on columns is referred to as PT Slab

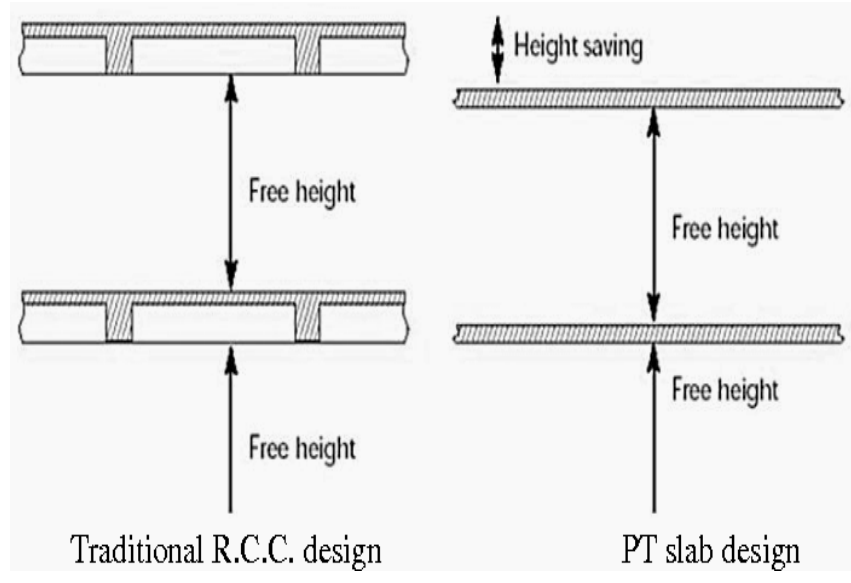

Fig. 2. Height of RCC \& PT slab. 


\section{A. Post Tensioned Slab -}

A cement-concrete slab under which tendons are stretch \& then freed such that the compressive strength works on the plate cross-section.

\section{Post-Tensioned Slab Benefits}

1. Span length over 6 meters is easier to use for PT slabs. Concrete quantity decreases of up to $25 \%$, and average reinforcement bars use of up to $65 \%$.

2. If shoring and formwork are not removed early on, formwork may be extracted until the tendons are stretched or tensioned. This helps in a shorter building schedule by getting access to the upper floors early.

3. The PT concrete structure results in less permeable and denser concrete that less cracks.

4. Up to 9-meter-long span for 2-way PT roof systems are sometimes used, enabling more compact occupant positioning and improved sight lines.

5. Structural components, especially columns and shear walls, are lighter and thinner due to the use of posttensioned slabs.

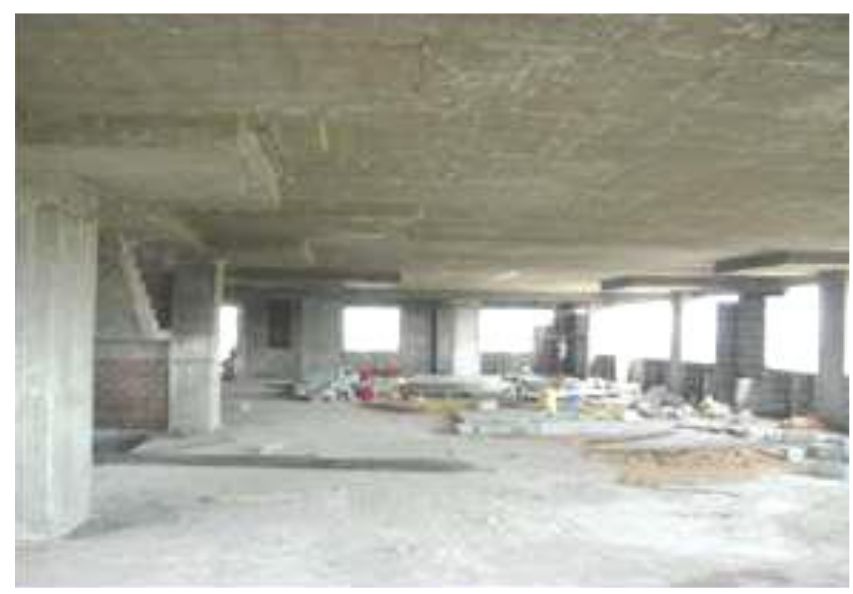

Fig. 3. Flat Slab (with drop).

\section{Post-Tensioned Slab Drawbacks}

1. As the tendon and nerve conduits are enclosed in the concrete slab, they are vulnerable to corrosion. However, the consistency of tendons is critical for corrosion resistance.

2. Due to the difficulty of building only qualified construction workers may fabricate PT slabs. The regional labours don't have the expertise needed to create this complicated system.

3. The critical issue of utilizing post tension slabs is that caution must be taken during building to maintain durability and prevent potential injuries. So detailed work should be necessary to achieve this mission.

\section{B. Flat Slab -}

It is considered as two-way RCC plate under which load is transmitted from the plate to the column directly rather than depending on beams.

\section{Flat Slab Benefits}

1. The availability of higher ceiling heights is better.

2. Ease of managing form-work and thus not as expensive.

3. A flat ceiling can offer a pleasing, appealing appearance to the room.

4. Floors are placed beneath columns instead of beams for greater visibility.

\section{Flat Slab Demerits}

1. A higher span cannot be longer than 2.2 times of limited range.

2. Live load of plate shouldn't be exposed to more than three times its own weight.

3. The slab broadness criterion is mostly in the case of a flat plate $\&$ the broadness of the plate must be greater as compared to $125 \mathrm{~mm}$.

4. The slabs are more resilient compared to beams and less resistant to seismic impact.

\section{RESULTS COMPARSION}

\section{Boskey Vishal Bahoria et al. [1]}

Table -1 Quantity Comparison.

\begin{tabular}{|c|c|c|c|c|}
\hline ITEMS & $\begin{array}{c}\text { CONCRETE } \\
\left(\mathbf{M}^{\mathbf{3}}\right)\end{array}$ & $\begin{array}{c}\text { STEEL } \\
(\mathbf{K G})\end{array}$ & $\begin{array}{c}\text { TENDON } \\
(\text { KG })\end{array}$ & $\begin{array}{c}\text { FORM } \\
\text { WORK }\end{array}$ \\
\hline PT slab & 507.52 & 31659 & 8400 & 2100 \\
\hline $\begin{array}{c}\text { RCC } \\
\text { flat slab }\end{array}$ & 549.69 & 85550 & --- & 2100 \\
\hline $\begin{array}{c}\text { PT with } \\
\text { beams }\end{array}$ & 641.33 & 42271 & 6720 & 2100 \\
\hline $\begin{array}{c}\text { Typical } \\
\text { RCC }\end{array}$ & 626.31 & 86701 & --- & 2100 \\
\hline
\end{tabular}

1. Concrete $=4400 /-$ per $\mathrm{m}^{3}$.

2. Steel $=50 /$ - per $\mathrm{kg}$.

3. Form work $=400$.

4. Tendon $=130 /$ - per $\mathrm{kg}$.

Based on this research, several observational findings were made.

$>$ From the economic standpoint, post-tensioned flat slab is the most economic system, whereas concrete slab with strengthened beams is comparatively more costly. 
$>$ The reinforcement steel is more important in posttensioned slab beam construction due to the role of the steel in transferring the load to the concrete beam.

$>$ The amount of cement-concrete needed for a slab is higher in the case of reinforced concrete beams with posttensioned slabs than for the PT flat plate.

$>$ The reinforcing steel in the reinforced concrete flat slab weights 41 kilograms per square meter, while reinforcing steel in the reinforced concrete slab and beam weighs 40 kilograms per square meter.

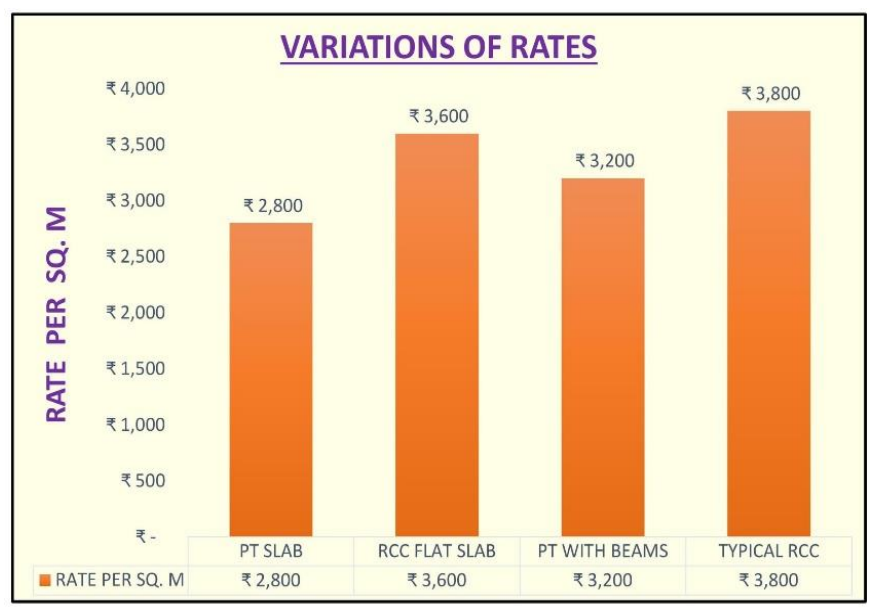

Fig. 4. Variation of rate for each case.

$>$ If we consider the time of construction for a floor, it is less for flat slab-type than for post-tensioned flat slab, as the post-tensioning enables earlier extraction of the formwork. When the formwork on the slab is stripped off, the formwork on the reinforced concrete pillars cannot be taken off as well.

$>$ For post-tensioned flat slabs, the quantity of pretensioning steel is $4 \mathrm{Kg} / \mathrm{m} 2$ and $3.2 \mathrm{Kg} / \mathrm{m} 2$ for posttensioned slabs with reinforced concrete beams, i.e., the pre-tensioning steel needed for the post-tensioned flat slab is greater.

$>$ Reinforcing steel used in the post-tensioned and posttensioned concrete beams is 15 kilograms per square meter $(\mathrm{Kg} / \mathrm{m} 2)$ and 20.15 kilograms per square meter $(\mathrm{Kg} / \mathrm{m} 2)$, respectively.

\section{Thayapraba M. [2]}

Based on this research, several observational findings were made.

$>$ The study of floor systems of RCC and PT are achieved by using SAP. The limit state design of RCC slab systems is done as per IS guidelines.
$>$ For all the size of the panels evaluated, PT concrete floor structures has proven to be cost efficient than reinforced concrete floor structure.

$>$ The prices are now rising gradually in order to increase the size of the panels.

$>$ The amount of concrete used differs for various flooring systems, but the concrete used by RCC is more. This analysis may be applied to other panels and may help propose a specific slab framework that is more cost effective for the suitable situations.

\begin{tabular}{|c|c|c|c|c|}
\hline \multirow{2}{*}{$\begin{array}{l}\text { PANEL } \\
\text { SIZE } \\
(\mathbf{M})\end{array}$} & \multicolumn{2}{|c|}{$\begin{array}{c}\text { COLUMN STRIP } \\
\text { MOMENTS } \\
\text { (PT SLAB) }\end{array}$} & \multicolumn{2}{|c|}{$\begin{array}{c}\text { COLUMN STRIP } \\
\text { MOMENTS } \\
\text { (RCC FLAT } \\
\text { SLAB) }\end{array}$} \\
\hline & $\begin{array}{l}\text { MAXI } \\
\text { MUM } \\
(+V E)\end{array}$ & $\begin{array}{l}\text { MAXI } \\
\text { MUM } \\
(-V E)\end{array}$ & $\begin{array}{l}\text { MAXI } \\
\text { MUM } \\
(+\mathrm{VE}) \\
\end{array}$ & $\begin{array}{r}\text { MAXI } \\
\text { MUM } \\
(-V E)\end{array}$ \\
\hline $8 \times 8$ & 17.91 & -139.04 & 20.33 & -174.04 \\
\hline $9 \times 9$ & 21.19 & -182.47 & 24.3 & -214.9 \\
\hline $10 \times 10$ & 25.49 & -243.93 & 28.2 & -315.2 \\
\hline $11 \times 11$ & 33.12 & -327.31 & 41.29 & -430.05 \\
\hline $12 \times 12$ & 44.4 & -423.08 & 58.9 & -548.63 \\
\hline
\end{tabular}

Table -2 Column strip moments

Table -3 Middle strip moments.

\begin{tabular}{|c|c|c|c|c|}
\hline \multirow{2}{*}{$\begin{array}{c}\text { PANEL } \\
\text { SIZE } \\
\text { (M) }\end{array}$} & \multicolumn{2}{|c|}{$\begin{array}{c}\text { MIDDLE STRIP } \\
\text { MOMENTS } \\
\text { (PT SLAB) }\end{array}$} & \multicolumn{2}{c|}{$\begin{array}{c}\text { MIDDLE STRIP } \\
\text { MOMENTS } \\
\text { (RCC FLAT } \\
\text { SLAB) }\end{array}$} \\
\cline { 2 - 5 } & $\begin{array}{c}\text { MAXI } \\
\text { MUM } \\
\text { (+VE) }\end{array}$ & $\begin{array}{c}\text { MAXI } \\
\text { MUM } \\
\text { (-VE) }\end{array}$ & $\begin{array}{c}\text { MAXI } \\
\text { MUM } \\
\text { ++VE) }\end{array}$ & $\begin{array}{c}\text { MAXI } \\
\text { MUM } \\
\text { (-VE) }\end{array}$ \\
\hline $8 \times 8$ & 14.23 & -8.74 & 16.1 & -10.82 \\
\hline $9 \times 9$ & 18.5 & -10.1 & 20.93 & -11.79 \\
\hline $10 \times 10$ & 21.23 & -14.18 & 23.56 & -15.83 \\
\hline $11 \times 11$ & 27.51 & -17.24 & 31.5 & -24.04 \\
\hline $12 \times 12$ & 37.4 & -19.95 & 44.56 & -30.79 \\
\hline
\end{tabular}




\section{International Journal of Engineering Applied Sciences and Technology, 2021 \\ Vol. 6, Issue 1, ISSN No. 2455-2143, Pages 117-121 \\ Published Online May 2021 in IJEAST (http://www.ijeast.com)}

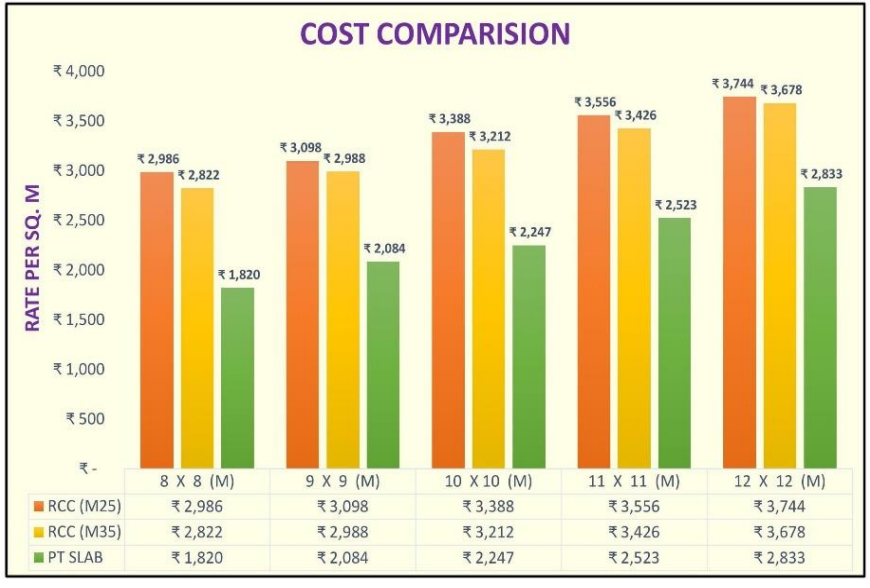

Fig. 5. Cost comparision.

\section{CONCLUSION}

$>$ The moment of the PT slab was reduced by equal frame method, relative to the moment of the RCC flat plate, as the depth of the PT slab was 30 to $35 \%$ lower than RCC slab since its self-weight was reduced.

$>$ For enhancing shear force and moment of post-tensioning of flat plate slab on column so there is a significant zero impact to axial force.

$>$ The amount of slab steel used in P/T slab is $25 \%$ less than the amount needed in the traditional slab. On flat slab or PT flat slab, only horizontal beams are provided.

$>$ In R.C.C. construction, building formwork time is shortened, and work charges are reduced relative to R.C.C. In the case of post-tensioned flat floors.

$>$ PT used for the slab is more helpful than the typical slab form. It's affordable, simple to create, is better for extended panels, offers an architectural look, retains slab thickness, more resistant to seismic, durable, and live.

$>$ It is important to design high elevated public or residential structure on the basis of safety and the workability of the structure. Other forms of flat slabs have more drawbacks than the PT slab.

$>$ PT-slab has great stability as compared to traditional system owing to the greater number of story displacements in seismic research, but in PT flat slab boundary beams are provided to preserve structural integrity during earthquakes.

\section{REFERENCE}

[1] Boskey Vishal Bahoria, Dhananjay K. Parbat, "Analysis and Design of RCC and Post-tensioned Flat Slabs Considering Seismic Effect" International Journal of Engineering and Technology, Vol. 5, No. 1, February 2013. (Pg. $10-13)$.

[2] Thayapraba M, "Cost Effectiveness of Post - Tensioned and Reinforced Concrete Flat Slab Systems," International Journal of Innovative Technology and
Exploring Engineering (IJITEE) ISSN: 2278-3075, Volume-3, Issue-12, May 2014. (Pg. 107 - 109).

[3] E. H. K. Park, "RC Flat Plate under Combined in-Plane \& Out-Of-Plane Loads," Journal of Structural Engineering, vol. 125, no. 10, October, 1999. (Pg. 1136 - 1142).

[4] Y. H. Luo and A. Durrani, "Equivalent Beam Model for Flat-Slab Buildings: Interior Connections," ACI Structural Journal, vol. 92, no.1, 1995. (Pg. 115 - 124).

[5] Kamal Padhiar, Dr. C.D. Modhera, Dr. A. K. Desai, "Comparative Parametric Study For Post-Tension Flat Slab And Flat Slab With Drop System" International Journal of Civil Engineering and Technology, Volume 8, Issue 5, May 2017. (Pg. 33 - 41).

[6] Anusha. I. Koti, Dr. S. B. Vanakudre, "Analysis of PT flat slab with Drop- Considering Seismic Effect" International Research Journal of Engineering and Technology, Volume: 05 Issue: 06 | June-2018. (Pg. 119 126).

[7] Shriraj S. Malvade, P.J. Salunke, "Analysis of PostTensioned Flat Slab by using SAFE" International Journal of Scientific Engineering and Applied Science,Volume-3, Issue-3, March 2017. (Pg. 92 - 95).

[8] Amrut Manvi, Sandeep Gouripur, Pooja Sambrekar, Ramanjeet kaur, Dr. Kishor S. Kulkurni, "Cost Comparison Between Conventional And Flat Slab Structures", International Research Journal of Engineering and Technology, Volume: 02 Issue: 03 | June-2015. ( $P g .1218$ - 1223).

[9] Mohana H.S, Kavan M.R, "Comparative Study of Flat Slab and Conventional Slab Structure Using ETABS for Different Earthquake Zones of India" International Research Journal of Engineering and Technology, Volume: 02 Issue: 03 | June-2015. (Pg. 1931 - 1936).

[10] Navyashree K, Sahana T.S (2014), "Use of flat slabs in multi-storey commercial building situated in high seismic zone", IJRET: International Journal of Research in Engineering and Technology, 3.(Pg. 439 -451).

[11] Vakas K. Rahman, Prof. A.R. Mundhada (2013), "Comparative study of RCC and Prestressed concrete flat slabs", International Journal of Modern Engineering Research (IJMER). (Pg. 1727 - 1730).

[12] Dr. Uttamasha Gupta, Shruti Ratnaparkhe and Padma Gome, "Seismic Behaviour of Buildings Having Flat Slabs with Drops," International Journal of Emerging Technology and Advanced Engineering ISSN 2250-2459, Volume 2, Issue 10, October 2012. (Pg. 416 - 421).

[13] Dr. B. Ramesh Babu 1, Rangana Manoj Kumar2, C. Umamaheshwar3, "Analysis on design of flat slab structure" ISSN (Online): 2319-8753, Vol. 6, Issue 1, January 2017. 